\title{
Health Educational Program to Enhance Self Concept among Female Secondary School Students about Body Image
}

\author{
Reham Ali Kamal ${ }^{1}$, Mahbouba Sobhy Abd EI - Aziz ${ }^{2}$ and Samah Said Sabry ${ }^{3}$ \\ (1) Specialist nursing, Central Hospital of Kafr Shokr, EL Qalubia Governorate, (2)Professor of \\ Community Health Nursing, Faculty of Nursing, Benha University and (3) Assistant professor of \\ Community Health Nursing, Faculty of Nursing, Benha University
}

\begin{abstract}
Background: Self-concept is important to students' physical and psychological heath that results in the body image appearance. The aim of the study: Was to evaluate the effect of health educational program to enhance self-concept among female Secondary Schools students about body image. Research design: A quasi-experimental design was used. Setting: The study was conducted at Al-Shimaa Secondary School at Benha City. The sample: Systematic random sample was used, it included 110 students. Tools of data collection: Three tools were used I: A structured interviewing questionnaire to assess; part1) Demographic characteristics of students, part 2) Knowledge and practice of students regarding self-concept. II: Tennessee Self-Concept Scale was used to assess self-concept of students and III: Body Image lickert Scale used to assess body image of students. Results: $82.7 \%$ of female Secondary School students had good knowledge about selfconcept and body image, $89.1 \%$ of students had satisfactory practices, $50 \%$ of students had high self- concept, $51.8 \%$ had high body image, and there was highly statistically significant correlation between total self-concept and total body image. Conclusion: Female secondary school students' knowledge and practices about self-concept and body image at Al-Shimaa Secondary School were improved after program implementation. Recommendations: Students should use developed simplified and comprehensive Arabic booklet, developing intervention programs that enhance development of positive self-concept and future research is proposed generate the effect of health educational program to enhance self-concept among students about body image on larger scale.
\end{abstract}

Key words: Self-concept, Body image, Female secondary school students.

\section{Introduction:}

Secondary School period is the developmental period of transition between childhood and adulthood; this stage of education is complementary to the previous two stages (the primary and the intermediate stages) where the student personality gradually reaches maturity. It is accompanied by physical, cognitive, social and emotional changes that present opportunities and challenges for Secondary School students, family and broader community. It is place of gradual natural and comprehensive growth of students intellectual characteristics, these changes make students as a critical period for positive development of self-concept (Bixler and linton, 2020).

Internationally, Secondary schools students represent one fifth of world population. Represented 1.2 billion students $85 \%$ of Secondary students are in developing world. Secondary School students are 
estimated to be 56.7 million in public schools at the United States, 5.7 million in private schools, also Asia included 2.8 million students, .5 million students presented in India and .2 million students in Iceland (National Center for Education Statistics, 2020).

Self-concept is generally thought of individual behavior, abilities and unique characteristics. A mental picture of a person about self, so self-concept is a powerful construct that lies at the center of an individual's psychology connecting various dimension such as motivation, goals and strategic behaviors. Self-concept is a structural product of reflexive activity, but it is also susceptible to change as the individual encounters new roles, situations, and life transitions. Also self-concept is a general term used to refer to how someone thinks about, evaluate or perceives themselves (Kendra, 2020).

Body Image (BI) is the mental representation of persons bodies that presented in person's mind. It was believed that body image is a mirror image of what objectively exists in the world, more recent literature suggests that body image is strongly influenced by a variety of factors including psychological, social, cultural, biological, historical and individual factors. Body image is a construct that is implicated in eating disorder and body dysmorphic disorder, many individuals with these conditions experience inability to objectively perceive body appearance, size or shape (Roosen, 2021).

Body Image can also affect females more than males and had relationships with physical activity. Feeling self-conscious or uncomfortable with appearance or body size or shape can lead females to avoid physical activity. Females with negative body image have the risk of engaging in un healthy life style behaviors as dieting or restrictive eating, over exercising and other distorted eating or weight control behaviors. Females with positive body image became the better in all life dimensions and improve self-esteem, self-acceptance, and healthy relationship with food and physical activity (Mitten, 2020).

Relation between body image and selfconcept is great, because body image is one of the significant components of self-concept that provide the opportunity to reach a more healthy physical and mental state. In this way, the perception of student body and those feelings which are associated with this image greatly influence not only student self-concept, but student self-esteem too. Major differences between the perceived and ideal body images predicted lower levels of self-concept, furthermore distortions of visual perception were also explored by students with negative body image (American Psychology Association, 2021).

Community Health Nurses (CHN) have become health care professionals that possess a great deal of knowledge, this knowledge should be valued through skills and competences of $\mathrm{CHN}$ as educating students to select healthy life style choices that are a key to improve body image through improving self-concept. CHN provide students with opportunities to reach a more healthy physical, psychological and mental state (Ross, 2020).

\section{Significance of the study:}

Secondary schools students in Egypt are estimated to be 20.2 million, representing $21 \%$ percent of the country's population according to 2018 statistics. Self-concept has great impact on adolescents personality and behaviors, recent research suggests that low self-concept in students may be a portent for poor longer-term out comes as a fewer years of post-secondary education, greater probability of joblessness and financial difficulties as poorer mental/physical health 
and higher rates of criminal behaviors ( Egypt

Official Statistics Agency, 2018).

\section{Aim of the study:}

This study aimed to evaluate the effect of health educational program to enhance self-concept among female secondary schools students about body image.

\section{Research Hypothesis:}

- Health educational program will enhance self-concept among female Secondary School students.

- Health educational program will positively affect body image of female secondary school students.

\section{Subjects and method:}

\section{Research design:}

A quasi-experimental design was utilized in this study.

\section{Setting:}

The total number of secondary schools at Benha City are 4 secondary schools for girls ( Al-Shimaa Secondary School, Asmaa Bent Aby Bakr Secondary School, Benha girls secondary school and El-Saida Aisha secondary school). The study conducted at $25 \%$ from secondary schools (Al-Shimaa Secondary School) selected randomly from Benha City.

\section{Sampling:}

Systematic random sample was utilized from the previous setting by 1 every 4 student from total number of 686 from first and second grade according to attendance to school. The total number was 110 students chosen from first and second grade according to attendance to school.

Tools for Data Collection: Three tools were used to collect the data:
Tool (I): A structured interviewing questionnaire used in this study, it consisted of two parts:

Part1: Concerning demographic characteristics of female secondary school students consisted of 12 closed ended questions.

Part2 (A): Concerning knowledge of female Secondary Schools students about self-concept and body image consisted of 12 closed ended questions.

\section{Scoring system:}

Knowledge score for each answer was given as follows: 2 for complete \&correct answer, 1 for incomplete \& correct answer and 0 for incorrect answer, so total scores of knowledge $=24$ point $=100 \%$. All items of knowledge scores were considered good if the score of the total knowledge $>75 \%$ (> 18 score), while considered average if it is equal $50 \%-75 \%$ (12-18 score), and considered poor if it is less than $50 \%$ ( $<12$ score).

Part 2 (B): Concerning practice of female secondary Schools students as reported by the students about self-concept and body image consisted of 43 items.

\section{Scoring system}

Practice score for each answer was given as follows: Done and not done. These were respectively scored 1 for done, and 0 for not done. These scores of the items were summed -up and the total divided by the number of the items giving a mean score. These scores were converted into percent score. As well as students total practice score was classified as following:

Total scores of practice $=\mathbf{4 3}$

- Satisfactory: when the total score more than $>60 \%=(>26)$. 
- Unsatisfactory: when the total score less than $<60 \%=(<26)$.

\section{Tool II: Tennessee Self-Concept Scale} (TSCS) modified by (D' Zurilla et al., 2011) and adopted by the researcher to assess selfconcept of female secondary schools students consisted of 82 item likert type scale and distributing on the following domains: Moral self-concept, Prisoner side, Social self -concept, Physical and personal self-concept and Behavioral, practical and self-fulfilling. It consists of 10 statements, 5 statements are phrased positively and 5 statements are phrased negatively.

\section{Scoring system:}

Self-concept statements were rated on 5 point scale which are; (5) for absolutely correct response, (4) for often in correct response, (3) for in between response, (2) for often incorrect response and (1) for absolutely untrue response. Scoring of negative answers was reversed such as (5) for absolutely untrue response , (4) for often incorrect response, (3) for in between response, (2) for often in correct response and (1) for absolutely correct response. The total score of self-concept was calculated by summation of the scores of its statement.

Total scores of self-concept $=82$ point $=$ $100 \%$ All items of self-concept scores considered high when total score of selfconcept more than $75 \%$ (>308 score), while considered moderate if it is equal $50 \%-75 \%$ (205-308 score), and considered low if it is less than $50 \%$ (<205 score).

Tool III: Body Image lickert Scale ( BILS) developed by (D'Zurilla et al., 2011) adapted by researcher to assess body image of female secondary schools students. That includes female secondary schools students' body image that consists of 51 items.

\section{Scoring system:}

The score response for questions include (5) for always response, (4) for frequently response, (3) for Sometimes response, (2) for rarely response and (1) for never response. Total scores of body image $=51$ point $=$ $100 \%$. All items of body image scores considered high when total score of body image was more than $75 \%$ (>192 score), while considered moderate if it is equal $50 \%$ $75 \%$ (128-192 score), and considered low if it is less than $50 \%$ (< 128 score).

\section{Content validity of the tools:}

The tools validity was done by five of Faculty's Staff Nursing experts from the Community Health Nursing Specialties who reviewed the tools for clarity, relevance, comprehensiveness, reliability and applicability.

\section{Reliability of the tools:}

The tools reliability was applied by the researcher for testing the internal consistency of the tools by administration of the same tools to the same subjects under similar condition on one or more occasion. The internal consistency of knowledge was 0.66 , for practice was 0.62 , for self-concept was 0.71 and 0.89 for body image.

\section{Pilot study:}

The pilot study was conducted on $(10 \%)$ of the studied sample size. The pilot study was aimed to test the feasibility, clarity, applicability of the tools and time needed to fill each sheet, completing the sheet consuming time about 10 to 15 minutes. No modifications were done, so the pilot study sample were included to the total sample.

\section{Ethical considerations:}

All ethical issues were assured; approvals to conduct the study was obtained 
from the Dean of Faculty of Nursing and authorized personnel concerning title, objectives, tools; the study technique. Oral consent was obtained from students and staff before conducting the interview and before giving them a brief orientation to the purpose of the study. They were also reassured that all information gathered will be treated confidentially and used only for the purpose of the study. They were assured that they have the right to withdraw from the study at any time without giving any reason.

\section{Field work:}

The study was carried out over a period from 20 September 2019 to 10 March 2020, the data was collected from students through interview of them after taking their acceptance to participate in the study and explaining the aim of the study the researcher was attended two days/week for Al-Shimaa Secondary School from 9.00 am to $2.00 \mathrm{pm}$ with application of sessions each session took about 30 to 45 minutes.

The researcher implemented the intervention through three phases as the following:

\section{Preparatory phase:}

Assess knowledge and practices of female Secondary Schools students about self-concept that affect body image.

\section{Implementation phase:}

The interview questionnaire conducted by the researcher for data collection in the selected setting, after getting the necessary official permission; the researcher introduced herself and asked the questionnaire used simple Arabic language. Implementation of the program done through sessions, the number of sessions were 10 ( 7 theoretical and 3 practical), the expected duration of each session was from
30 to 60 minutes, used group discussion also booklet utilized, with clearance of general and specific objectives as follow:

\section{General objectives:}

By the end of educational program , the female Secondary School students acquired knowledge, skills and attitude related to improving body image, achieving high levels of self-esteem and selfactualization.

\section{Specific objectives:}

- Recognize basic rules of health educational program.

- Define self-concept and identify factors that increase self-actualization.

- Determine steps of achieving selfactualization and self-esteem, causes of self-esteem deficiency and define steps for achieving self-esteem.

- Enumerate define factors that affect on achieving the ideal Body Image.

- List methods of personal cleanliness and practice health habits for body caring as showering, hair hygiene, washing teeth and cutting nails.

- Differentiate between different types of physical exercises and practice sport for achieving ideal Body Image.

- Explain ways for achieving the ideal Body Image and remember the effect of dietary habits on Body Image.

- Define the relation between self-concept to Body Image, trained students on strategies that improving Body Image through improving negative self-concept.

- Describe ideal Body Image and achieving self-concept based on ideal Body Image.

- Evaluate the impact of the program on the female Secondary School students' knowledge about self-concept and Body Image as well as the relation between them. 
First session: At the beginning of the first session, the researcher introduced herself to female Secondary Schools students, an orientation to the intervention was given, take oral informed consent of students, set an agreement on the number, time and duration of sessions. The researcher provided a trust, warm and secured atmosphere between students and relieved anxiety, tension and increased motivation for participate in all sessions of the nursing intervention provided introduction about meaning of program, basic rules and expectations of students about program. Second session: Covered meaning of self-concept and factors that increased self-actualization. Third session: determined steps of self- actualization, causes of decreasing self- esteem, steps of achieving self- esteem. Fourth session: enumerate factors that affected on achieving the ideal Body Image. Fifth session: In this session students listed methods of personal cleanliness and practiced healthy habits for body caring. Sixth session: In this session students differentiate between types of physical exercise and practicing sport to achieve the ideal body image. Seventh session: Explained to students' methods for achieving the ideal body image and remember the effect of food habits on Body Image. Eighth session: Defined the relation between self-concept to Body Image, trained students on strategies that improving Body Image through improving negative selfconcept by using booklet. Ninth session: described to students the ideal Body Image and achieving self-concept that related to ideal Body Image by using booklet. Tenth session: Evaluate the impact of the program on the female Secondary School students knowledge by teaching students to apply strategies that helped them became more assertiveness and improving students' information about self- concept and its impact on achieving ideal body image. In this session the posttest knowledge questionnaire was introduced self-concept and Body Image scale was provided immediate finishing the all sessions. Explained to the students that this was the last meeting for evaluating the effectiveness of the intervention and provided the post test tools.

\section{Evaluation phase:}

Evaluation of the program was done immediately and after the end of the program by using the same pre/ post test questions.

\section{Statistical design:}

The collected data were organized, tabulated and analyzed using appropriate statistical test. The data were analyzed by using the Statistical Package for Social Science (SPSS) , that was used to calculate frequencies and percentages mean and standard deviation, also statistical significance and associations by using Chi-square test, it was a test used to study association between two qualitative variables and matrix correlation to detect the relation between the variables for ( $p$ value).

\section{The observation difference and associations were considered as following:}

$\begin{array}{ll}\text { Highly significance (HS) } & \mathrm{p}<0.001 \\ \text { Significance (S) } & \mathrm{p}<0.005 \\ \text { Not significant (NS) } & \mathrm{p}>0.005\end{array}$

\section{Results}

Table (1): Shows that; $76.4 \%$ of studied students are aged 15years or more with mean age $17.52 \pm 2.14$. $56.4 \%$ of students are from rural areas. Regarding arrange among brothers $48.2 \%$ of students are the third arrangement among brothers.

Table (2): Shows that; $67.3 \%$ of studied students' family members ranges from 3 to 5 


\section{$\underline{\text { Reham Ali Kamal, Mahbouba Sobhy Abd El - Aziz and Samah Said Sabry }}$}

members. $56.4 \%$ of students' mothers are working. $50 \%$ of students' father ages are from 40 years old or more with mean age $42.81 .54 \pm 6.83$.

Figure (1): Reveals that; $20 \%$ of studied students had good knowledge about selfconcept and body image pre-program, however post program increased to $82.7 \%$. While $61.8 \%$ of them had average knowledge pre-program compared by $11.8 \%$ post program, and $18.2 \%$ of students had poor knowledge pre-program and post program decreased to $5.5 \%$.

Figure (2): Reveals that; $70.9 \%$ of studied students' practices were unsatisfactory at preprogram intervention compared to $10.9 \%$ of students post program implementation. And $29.1 \%$ of students with satisfactory practices at pre- program implementation and increasedto89.1\%postprogramimplementation Figure (3): Reveals that; $37.3 \%$ of studied student's self- concept was high at preprogram and increased to $50.0 \%$ postprogram. While $34.5 \%$ of students' selfconcept was moderate at pre-program and increased to $38.2 \%$ post-program. Also $28.2 \%$ of students' self- concept was low at preprogram and decreased to $11.8 \%$ postprogram. The figure illustrate that, there were highly statistically difference about all items regarding students self- concept total score pre and post program implementation.

Figure (4): Reveals that; $37.3 \%$ of studied students' body image was high during implementation pre-program and increased to $51.8 \%$ post-program. While $50.0 \%$ of students' body image was moderate at preprogram and decreased to $37.3 \%$ postprogram. Also 1 r. $7 \%$ of students' body image was low at pre-program and decreased to 10.9 $\%$ post-program.

Table (3): Shows that; there was statistically significant correlation between total practices, self-concept, body image and total knowledge during pre-post program ( $\mathrm{p}<0.005$ ).

Table (4): Shows that; there was highly statistically significant correlation between total self-concept and total body image during pre-post program implementation $(\mathrm{p}<0.001)$.

Table (1): Frequency distribution of studied students regarding their demographic characteristics $(n=110)$.

\begin{tabular}{|l|c|c|}
\hline \multicolumn{1}{|c|}{ Items } & No. & $\%$ \\
\hline Age & 6 & 5.5 \\
\hline $12-$ & 4 & 3.6 \\
\hline $13-$ & 16 & 14.5 \\
\hline $14-$ & 84 & 76.4 \\
\hline 15 years + & \multicolumn{2}{|c|}{} \\
\hline \multicolumn{3}{|c|}{ Mean \pm SD $17.52 \pm 2.14$} \\
\hline Residence & 62 & 56.4 \\
\hline Rural & 48 & 43.6 \\
\hline Urban & 28 & 25.5 \\
\hline Arrange among siblings & 53 & 48.2 \\
\hline Second & 29 & 26.4 \\
\hline Third &
\end{tabular}


Health Educational Program to Enhance Self Concept among Female Secondary School Students about Body Image

Table (2): Frequency distribution of studied students regarding family characteristics $(\mathbf{n}=110)$.

\begin{tabular}{|c|c|c|}
\hline Items & No. & $\%$ \\
\hline \multicolumn{3}{|l|}{ Father age } \\
\hline $40-$ & 55 & 50.0 \\
\hline $45-$ & 21 & 19.1 \\
\hline $50-$ & 23 & 20.9 \\
\hline 55 years + & 11 & 10.0 \\
\hline \multicolumn{3}{|c|}{ Mean \pm SD $\quad 42.54 \pm 6.83$} \\
\hline \multicolumn{3}{|c|}{ Father educational level } \\
\hline Read and write & 41 & 37.3 \\
\hline Basic education & 26 & 23.6 \\
\hline Secondary Education & 43 & 39.1 \\
\hline \multicolumn{3}{|l|}{ Father job } \\
\hline Employee & 35 & 31.8 \\
\hline Freelancer & 27 & 24.5 \\
\hline Pension & 48 & 43.6 \\
\hline \multicolumn{3}{|l|}{ Mother age } \\
\hline $35-$ & 45 & 40.9 \\
\hline $40-$ & 34 & 30.9 \\
\hline $45-$ & 31 & 28.2 \\
\hline \multicolumn{3}{|c|}{ Mean \pm SD $\quad 37.28 \pm 5.62$} \\
\hline \multicolumn{3}{|c|}{ Mother educational level } \\
\hline Read and write & 14 & 12.7 \\
\hline Basic education & 40 & 36.4 \\
\hline Secondary education & 22 & 20.0 \\
\hline University education & 34 & 30.9 \\
\hline \multicolumn{3}{|l|}{ Mother occupation } \\
\hline Employed & 62 & 56.4 \\
\hline Housewife & 48 & 43.6 \\
\hline \multicolumn{3}{|l|}{ Family number } \\
\hline $3-5$ & 74 & 67.3 \\
\hline $5-7$ & 36 & 32.7 \\
\hline \multicolumn{3}{|l|}{ Family income } \\
\hline Enough and save & 55 & 50.0 \\
\hline Enough only & 55 & 50.0 \\
\hline
\end{tabular}




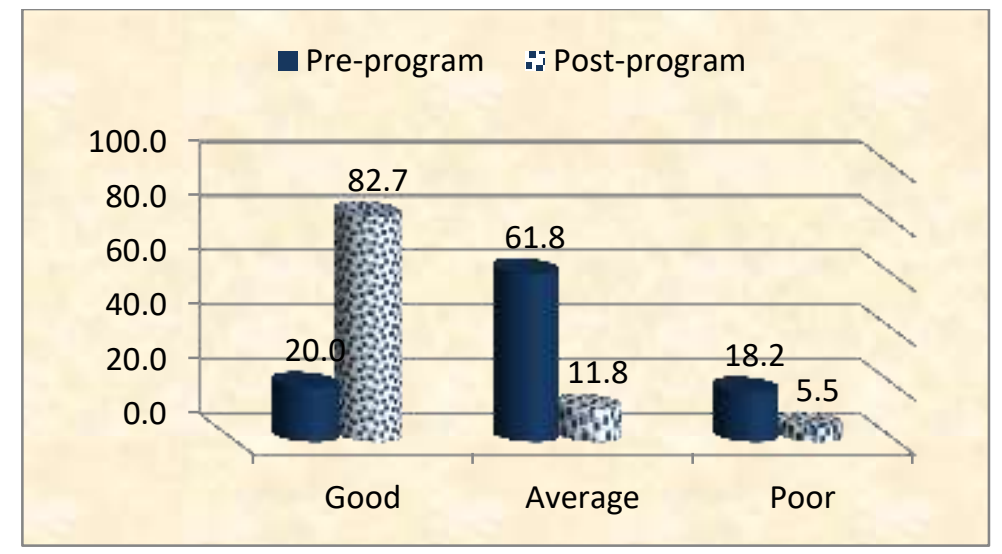

Figure (1): Percentage distribution of studied students regarding their total knowledge about self-concept and body image pre-post $(n=110)$.

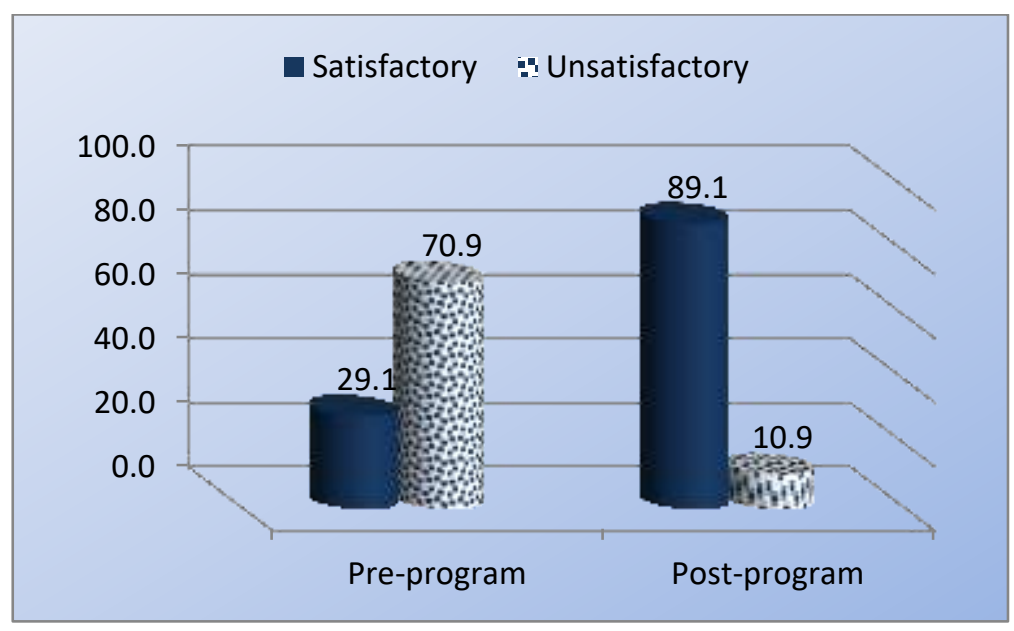

Figure (2): Percentage distribution of studied students regarding their total reported practices score pre-post program implementation $(n=110)$.

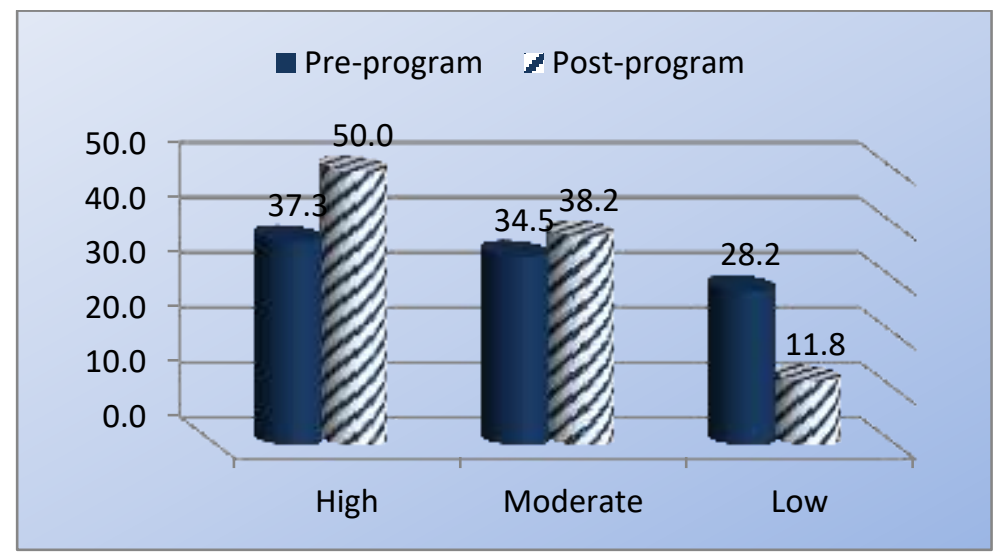

Figure (3): Frequency distribution of studied students regarding total self- concept score pre-post program implementation $(\mathbf{n}=\mathbf{1 1 0})$. 


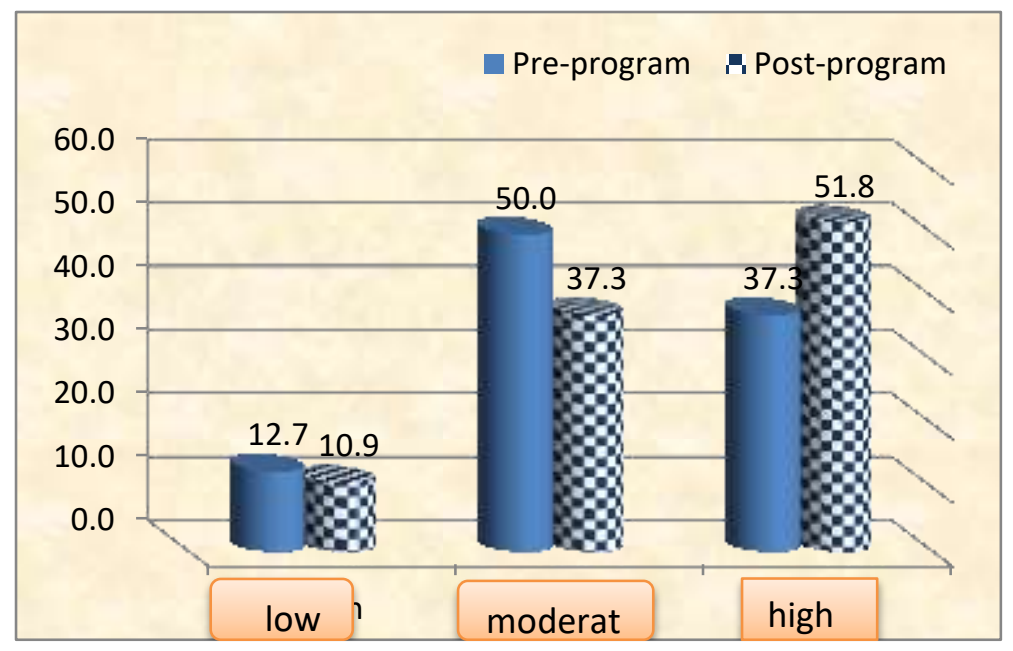

Figure (4): Distribution of studied students regarding total body image score pre and post program implementation $(\mathbf{n}=\mathbf{1 1 0})$.

Table (3): Correlation between total knowledge, total practices, self-concept and body image pre and post program $(n=110)$.

\begin{tabular}{|l|l|l|l|l||}
\hline \multicolumn{1}{|c|}{ Items } & \multicolumn{2}{c|}{ Knowledge } \\
\cline { 2 - 5 } & \multicolumn{2}{c|}{ Pre } & p-value & \multicolumn{2}{c|}{ r. } & p-value \\
\hline \hline Total practices & 0.24 & $0.011^{*}$ & 0.18 & 0.053 \\
\cline { 2 - 5 } Self-concept & 0.34 & $0.000^{*} *$ & 0.05 & 0.59 \\
\cline { 2 - 5 } Body image & 0.211 & $0.027^{*}$ & 0.45 & 0.64 \\
\hline
\end{tabular}

** High statistically significant difference $(\mathbf{p}<0.001) *$ Statistically significant difference $(\mathbf{p}$ $<\mathbf{0 . 0 0 5 )}$.

Table (4): Correlation between self-concept and body image pre and post program.(n=110)

\begin{tabular}{|c||c|c|c||c|}
\hline \multicolumn{4}{|c|}{ Total self-concept } \\
\hline \multirow{2}{*}{$\begin{array}{c}\text { Total body } \\
\text { image }\end{array}$} & Pre & p-value & Post & p-value \\
\cline { 2 - 5 } & r. & & r. & $0.000^{* *}$ \\
\cline { 2 - 4 } & 0.621 & $0.006^{*}$ & 0.766 & \\
\hline
\end{tabular}

** High statistically significant difference $(\mathrm{p}<0.001)$. difference $(\mathrm{p}<0.005)$. 


\section{Discussion:}

Secondary School students are the future masters of the society. A clear and well-developed identity and favorable selfconcept promise positive development through students and even across a whole life span. Self-concept is crucial to a student's health and well-being throughout life that is the mental image or picture of self, has the power to encourage personal growth (Taylor et al., 2018).

This study was aimed to evaluate the effect of health educational program to enhance self-concept among female Secondary Schools students about body image through assessing female Secondary Schools students knowledge, practice and attitude regarding self-concept, developing, implementing and evaluating the effect of health educational program to enhance selfconcept among female Secondary Schools students that affect body image.

According to demographic characteristics of studied students the findings of the present study revealed that, the studied sample consisted of 110 female students with the mean age $17.52 \pm 2.14$. This finding agreed with Ram, (2019) who studied "The Effect of Nursing Intervention Protocol for Norwegian Female Secondary School Students to Empower Self- Concept" on 210 female students found that the mean age of the studied students' was $17.52 \pm 2.13$.

Regarding arranges among brothers the current study showed that, less than half of students were the third arrangement among brothers. This result consisted with Chinaveh, et al., (2019) who studied "The Secondary School Students Home Environment" on 155 female students in Boland, found that less than half of students were the third arrangement among brothers.
Regarding numbers of the family members the present study showed that, more than three fifth of studied students their family members ranged from 3 to 5 members. This result is contradicted with Bandy, (2018), who conducted study about "Number of Family Members among Female Secondary School Students" in Chicago, on 122 female students revealed that less than two fifth (38\%) of the study sample their family members ranged from 1 to 3 members. This might be due to the most of students families lived in rural areas and the most common attributes at these areas are that people like to have more children.

Regarding mother's work the present study showed that, more than half of studied students mothers worked. This result consistent with Mccloskey, (2019), who studied "Working Mothers and Secondary Education" on 400 female students in California University, reported that more than half of female secondary school students mothers worked. While inconsistent with Paton, (2020), who conducted a study about "Mothers Work" among Norwegian students reported that Secondary School students mothers rarely prefer to work. This result might be due to the progress in educational level in our society and increase interest in education and work of the females.

According to the female Secondary School students total knowledge regarding self-concept and body image pre and post implementing the program the study revealed that, the majority of studied students had a good knowledge. This result was congruent with the study conducted by Davoodi and Askari, (2018), about "Exploring Factors that Increase Students Knowledge about SelfConcept and It's Relation with Body Image" on 115 students in 5 secondary school in Singapore to explore factors that increase 
students knowledge about self-concept and it's relation with body image, found that the majority of students had good knowledge about the subject. This finding might be due to the effectiveness of the educational program and the experience that gained from group discussion and emotional expression with each other during the sessions.

Regarding female Secondary School students total reported practices score pre and post program implementation the results of the study revealed that, the majority of studied students total practices were satisfactory. This result was contradicted with Oslin, (2019), who studied "Accurate Assessment for Students Social, Personal and Family Practices" on 250 female students in Oxford and found that one fifth of the studied samples practiced good behaviors about personal, social and family practices. This might be due to differences of culture among generations in additional to the effect of media.

Regarding correlation between total knowledge ,total practices, self-concept and Body image, in the current study there was statistical positive correlation between total knowledge, total practices, self-concept and Body image, this finding was in the same line with Charulata, (2018), who studied "Body Image Satisfaction, Self-Concept, Practices that Related to Self - Concept and Body Image and Relation with Knowledge on Female Secondary School Students" in Manitoba and found that, there was a positive correlation between total knowledge, total practices, self-concept and body image. This result might be due to application of educational program.

In the current study there was highly statistically significant correlation between total self-concept and total body image during pre-post program implementation
$\mathrm{P}>0.001$ (Table.4), This results supported by Arthur, (2017), that conducted a study about "Secondary School Students Self- Concept and Body Image Pre-Post Program" at USA and found a significant correlation between total self-concept and total body image pre and post implementation of the health educational program.

\section{Conclusion}

The majority of female Secondary School students had good knowledge about self-concept and body image post program implementation compared to one fifth at preprogram, the majority of students had satisfactory practices at post program implementation compared to less than one third at preprogram, half of students had high self- concept at post program implementation compared to less than two fifth at preprogram, more than half of students had high body image at post program implementation compared to less than two fifth at preprogram, there was statistically significant correlation between total practices, self-concept, body image and total knowledge during pre-post program, there was high statistically significant correlation between total selfconcept and total body image during pre-post program implementation.

\section{Recommendations:}

- Arabic booklet that including information about self-concept among female Secondary School about body image should be made available in the Secondary School.

- Developing intervention programs that equip Secondary School students with effective strategies that could enhance development of positive self-concept.

- Future research is proposed to explore and generate the effect of health educational program to enhance self-concept among female Secondary School students about body image on larger scale. 


\section{References}

American Psychology Association (2021). Relationship of Body Image to Self Concept, Accessed on 2021, Available at: www.psycnet.apa.org

Arthur, M. (2017). Self-Concept and Body Image Disturbance, Journal of Cognitive therapy and research, Vol 18 (105), P 105.125, Accessed on 2021, Available at: www.researchgate.com

Bandy, Z. (2018). The House Life Among Female Secondary School Students, The Online Journal of Counseling and Education Vol 2(3), P 16-32, Accessed on 2019.

Bixler, H. \& linton, C. (202 •). The Students: Their Characteristics and Needs, Journal of Educational Research, Vol 12(1), P 5-20, Accessed on Feb2021, Available at: https://www.jstor.org/stabl

Charulata, G. (2018). The Relation Between Body Image, Self Concept Total Knowledge and Practices, Psychology Journal, Vol 22(9), P121-133, Accessed on 2020,Availableat: https://doi.org/10.1016/j.jcps.2015.0

Chinaveh, O. , Parto, A. , \& Besharat, S. (2019). Life of Secondary School Students, $2^{\text {nd }}$ ed, America, (bbk: alk paper), ISBN : 556-0-8046-4704-7, P 23-25.

Davoodi, M. \& Askari, C. (2018). Examining The Impact of Teaching Self Concept, Psychiatric Nursing Journal, Vol 4(3), p 186194, Accessed on 2021.

\section{Egypt's Official Statistics Agency (2018).}

Egypt's Populations ,Accessed on Sunday 12 August , 2018, Available at: https://www.egypttoday.com/article/1/55806/ca mpas-youth

Kendra, C. (2020). The Psychological Exploration of "Who Am I?", Accessed on 2021,Available at: $\underline{w w w . v e r y w e l l m i n d . c o m}$

Mccloskey, J. (2019). Mothers Perceptions of Work among Secondary Education, Journal of Health Scholarship, Vol 33(4) ; p 276-287.

Mitten, D. (2020). The Nature of Body Image Beyond Dualism in Gender , Body and Environment, Journal of Educational Psychology, Vol 15 (10), P96-116, DOI : 10 .4324/ 9781315167244-7, New York, Accessed on 2021, Available at: www.researchgate.

National Center for Education Statistics (2020). Fast Facts: Back to School Statistics, Accessed on 2 March 2021, Available at: https://www.nces.ed.gov

Oslin, D. (2019). Student Involvement in Personal, Social and Family Aspects, Journal of Family Practice, Vol 23(3), P317-324, Accessed on June,2020, Available at: www.researchgate.com

Paton, G.(2020). Vince Cable: University degrees ' Superfluous to Many Jobs', The Telegraph, Accessed on 2020, Available at: https://www.telegraph.co.uk

Ram, A. (2019). Secondary School Students, $2^{\text {nd }}$ ed., Chatswood, NSW: EL Sevier, P 47-48, Accessed on 2 Jan 2021.

Roosen, M. (2021). Body Image Overview, Accessed on 2021, Available at: www.link.springer.com 
Ross, M. ( 2020). Self - Concept, Journal of Consulting and Clinical Psychology, Vol 32 (1), P100 - 110, DOI:10.1037/h0025433, Accessed on 2020, Available at: www.psycnet.com

Taylor, V., Bona, G., \& Bozzola, M. (2018). Who Secondary School Student, Journal ArticleVol 7(2):P10616,Accessedon2021 ,DOI: 10.1016/j.bodyim. 2020.01.001. 
برنامج تعليمى صحى لتعزيز مفهوم الذات لاى طالبات المدارس الثانوية تجاه صورة الجسم ريهام علي كمال - محبوبه صبحي عبد العزيز - سماح سعيد صبري

تعتبر طالبات المدارس الثانويه مستقبل الامم، لذا فان هذه الفترة هى فترة حرجه للتطور الايجابى لمفهوم الذات بسبب التغير ات الجسديه و المعرفيه و الاجتماعيه الرئيسيه التى تحدث خلال هذه التغير ات فى الحياه. لذلك هدفت هذه الدر اسة إلى تقييم تأثير البرنامج التعليمى الصحى على تعزيز مفهوم الذات لدى طالبات المدارس الثانوية فيما يتعلق بصور الجسم. وقد أجريت الدراسة في مدرسة الثيماء الثانوية ببنها بطريقة طالبه واحده من كل ع طالبات ويبلغ إجمالي عدد الطلاب فيها 7^ح طالبا لتكون العينة ـ 11 طالبه و تم اختيار الصف الاول والثانى بناءا على نسبة الحضور. حيث كثفت النتائج الطالبات لديهن معلومات و ممار اسات جيذه عن مفهوم الذات وصورة الجسم كما اوضحت نتائج الدر اسه وجود علاقه ذات دلاله احصائيه بين مفهوم الذات وصورة الجسم. كما أوصت الدر اسة بأهمية إجر اء البر امج و الدر اسات لتدريس الاستر اتيجيات الموجهة لطالبات الثانويه العامه وهيه مما لها تأثير إيجابي على صورة الجسم من خلال تحسين مفهوم الذات. 